\title{
Effect of insulin on renal sodium handling in hyperinsulinaemic Type 2 (non-insulin-dependent) diabetic patients with peripheral insulin resistance
}

\author{
P.Skøtt ${ }^{1,2}$, A. Vaag ${ }^{1}$, N. E. Bruun ${ }^{2}$, O. Hother-Nielsen ${ }^{1}$, M.-A. Gall ${ }^{1}$, H. Beck-Nielsen ${ }^{1}$ and H.-H.Parving $^{1}$ \\ ${ }^{1}$ Hvidøre Hospital, Klampenborg, and ${ }^{2}$ Department of Clinical Physiology and Nuclear Medicine, Glostrup University Hospital, \\ Copenhagen, Denmark
}

Summary. The sodium retaining effect of insulin was studied in ten Type 2 (non-insulin-dependent) diabetic patients (mean age 56 (43-73) years, mean body mass index 29.5 $\left.(24.2-33.7) \mathrm{kg} / \mathrm{m}^{2}\right)$ and eight age-matched control subjects (mean age 57 (43-68) years, mean body mass index 23.4 $\left.(20.8-26.6) \mathrm{kg} / \mathrm{m}^{2}\right)$. The renal clearances of ${ }^{99 \mathrm{~m}} \mathrm{Tc}-\mathrm{DTPA}$, lithium, sodium and potassium were measured over a basal period of $90 \mathrm{~min}$. Then insulin was infused at a rate of $40 \mathrm{mU} \cdot \mathrm{min}^{-1} \cdot \mathrm{m}^{-2}$. After an equilibration period of $90 \mathrm{~min}$, the clearance measurements were repeated during a new $90 \mathrm{~min}$ period. Blood glucose was clamped at the basal level (diabetic patients: $9.9 \pm 3.5$, control subjects: $5.3 \pm 0.5$ $\mathrm{mmol} / \mathrm{l}$ ) by a variable glucose infusion. Basal plasma insulin concentration was elevated in the diabetic patients $(0.12 \pm 0.05 \mathrm{vs} 0.05 \pm 0.02 \mathrm{pmol} / \mathrm{ml}, p<0.01)$. Insulin infusion resulted in comparable absolute increments in plasma insulin concentrations in the diabetic group and in the control group $(0.44 \pm 0.13$ vs $0.36 \pm 0.07 \mathrm{pmol} / \mathrm{ml}, \mathrm{NS})$. The metabolic clearance rate of glucose during the last $30 \mathrm{~min}$ of insulin infusion was lower in the diabetic patients $(155 \pm 62$ vs $320 \pm 69 \mathrm{ml} \cdot \mathrm{min}^{-1} \cdot \mathrm{m}^{-2}, p<0.01$ ), reflecting peripheral in- sulin resistance. The decline in sodium clearance during insulin infusion was similar in diabetic subjects $(1.8 \pm 1.1$ vs $0.7 \pm 0.4 \mathrm{ml} \cdot \mathrm{min}^{-1} \cdot 1.73 \mathrm{~m}^{-2}, p<0.01$ ) and in control subjects $\left(1.7 \pm 0.3\right.$ vs $\left.0.8 \pm 0.3 \mathrm{ml} \cdot \mathrm{min}^{-1} \cdot 1.73 \mathrm{~m}^{-2}, p<0.01\right)$. The glomerular filtration rate and lithium clearance was unchanged, consequently calculated distal tubular fractional sodium reabsorption increased (diabetic patients: $92.9 \pm 4.1$ vs $97.1 \pm 1.5, p<0.01$, control subjects: $93.1 \pm 1.1$ vs $96.5 \pm 0.6 \%, p<0.01)$. Estimated extracellular fluid volume was $10 \%$ higher in the diabetic subjects $(16.3 \pm 2.1$ vs $\left.14.8 \pm 2.01 \cdot 1.73 \mathrm{~m}^{-2}, \mathrm{NS}\right)$. In conclusion, the sodium retaining effect of insulin is preserved in Type 2 diabetic patients with peripheral insulin resistance. Insulin may contribute to sodium and fluid retention and thus to the increased frequency of hypertension in hyperinsulinaemic Type 2 diabetic patients.

Key words: Glomerular filtration rate, lithium clearance, sodium excretion, potassium excretion, isoglycaemic clamp, insulin infusion.
Several conditions are characterized by peripheral insulin resistance (i.e. relative resistance to the glucose lowering effect of insulin), and concomitantly by elevated circulating plasma insulin levels. Prominent are the syndromes of Type 2 (non-insulin-dependent) diabetes mellitus, obesity, and essential hypertension [1-3].

Recently we found, that elevation of plasma insulin concentration within the physiological range has a marked antinatriuretic action located distally to the proximal renal tubules in young healthy subjects [4]. It has been proposed, that enhanced renal tubular sodium reabsorption due to hyperinsulinaemia may in part explain the sodium and fluid retention and the increased frequency of hypertension in obesity and Type 2 diabetes $[1,2,5]$. In contrast, it has been argued that the associated peripheral insulin resistance will counteract this renal effect [6].
The aim of the present study was to evaluate the renal effects of physiological increments in plasma insulin concentration in a state characterized by marked peripheral insulin resistance. Therefore, we studied a representative sample of Type 2 diabetic patients.

\section{Subjects and methods}

\section{Subjects}

We studied ten consecutive patients (two female, eight male) with Type 2 diabetes not receiving insulin treatment (Table 1) mean age 56 years (range $43-73$ years). Four were treated with diet alone and six received oral hypoglycaemic agents, which were withheld on the study day and the day before. Four patients had established arterial hypertension, but antihypertensive treatment had been withheld for 
Table 1. Clinical data in ten patients with Type 2 (non-insulin-dependent) diabetes mellitus and eight healthy control subjects

\begin{tabular}{lll}
\hline & $\begin{array}{l}\text { Type 2 diabetic } \\
\text { patients }\end{array}$ & Healthy subjects \\
\hline Number (female/male) & $10(2 / 8)$ & $8(2 / 6)$ \\
Age (years) & $56(43-73)$ & $57(43-68)$ \\
Body mass index $\left(\mathrm{kg} / \mathrm{m}^{2}\right)$ & $29.5(24.2-33.7)^{\mathrm{a}}$ & $23.4(20.8-26.6)$ \\
Blood pressure $(\mathrm{mm} \mathrm{Hg})$ & $134 \pm 15 / 81 \pm 12^{\mathrm{a}}$ & $116 \pm 18 / 72 \pm 12$ \\
Haemoglobin $\mathrm{A}_{1 \mathrm{c}}$ & $7.9 \pm 2.2^{\mathrm{b}}$ & $5.6 \pm 0.5$ \\
Retinopathy & $6 / 4 / 0$ & - \\
(none/background/proliferative) & & \\
\hline
\end{tabular}

Mean $\pm \mathrm{SD}$ or mean (range) indicated. ${ }^{\mathrm{a}} p<0.05 ;{ }^{\mathrm{b}} p<0.01$

at least four weeks before the study. Previous antihypertensive therapy was thiazide diuretic (two patients, one of these also received prazosin), captopril (one patient) and metoprolol (one patient). All patients had urinary albumin excretion rates $<300 \mathrm{mg} / 24 \mathrm{~h}$. The control group comprised eight age-matched healthy subjects (two female, six male) mean age 57 years (range 43-68 years). They were all normotensive and none was taking medication. In all control subjects an oral glucose tolerance test was normal, and none of them had a family history of diabetes. In both groups changes in the diet taken prior to the investigation were avoided. Allsubjects agreed to participate in the study after receiving oral and written information. The procedure was performed according to the principles of the Helsinki Declaration and the study was approved by the regional ethical committee.

\section{Methods}

The subjects received $600 \mathrm{mg}(16.2 \mathrm{mmol})$ of lithium carbonate (DAK Laboratory, Copenhagen, Denmark) orally the evening before the clearance study. The subjects fasted from midnight until the end of the study. During the clearance studies all the subjects were in the supine position, except when voiding urine. The subjects drank $200 \mathrm{ml}$ of tap water per $\mathrm{h}$ beginning one $\mathrm{h}$ before the start of the first clearance period.

During the investigation, each subject kept one hand in a heated plexiglas box to enable arterialized venous blood to be obtained. Blood glucose concentration was monitored in arterialized blood with a continuous glucose analyser (Biostator CGIIS, Life Science Instruments, Miles Laboratories, Elkhart, Ind., USA) connected to a forearm vein. Arterialized blood samples were drawn from a plastic catheter placed in another forearm vein on the same arm and after each blood sampling, the catheter was flushed with $5 \mathrm{ml} \mathrm{NaCl}$ $154 \mathrm{mmol} / \mathrm{l}$ in water. Insulin (Insulin Actrapid, Novo, Bagsværd, Derimark) dissolved in $\mathrm{NaCl} 154 \mathrm{mmol} / 1$ in water was infused through an antecubital vein in the contralateral arm. The insulin infusion was given at a constant rate of $11.6 \mathrm{ml} / \mathrm{h}$ with insulin added to provide an infusion rate of $40 \mathrm{mU} \cdot \mathrm{m}^{-2} \cdot \mathrm{min}^{-1}$. Through the same vein a variable infusion of $20 \%$ glucose was administered during insulin infusion. For determination of glucose turnover rates an adjusted primed-continuous infusion of $3{ }^{3} \mathrm{H}$-glucose was given. $3{ }^{3} \mathrm{H}$ glucose (New England Nuclear, Boston, Mass., USA) was dissoived in $\mathrm{NaCl} 154 \mathrm{mmol} / \mathrm{l}$ in water and infused at a rate of $25 \mathrm{ml} / \mathrm{h}$. During the study about $29 \mathrm{mmol} \mathrm{Na}$ was removed by blood sampling and about $36 \mathrm{mmol} \mathrm{Na}$ was given by infusions and flushing of catheters.

The renal clearances of ${ }^{99 \mathrm{~m}}$ Tc-DTPA, lithium, potassium and sodium were measured over a basal period of $90 \mathrm{~min}$ beginning $30 \mathrm{~min}$ after i.v. injection of approximately $100 \mathrm{MBq}{ }^{99 \mathrm{~m}} \mathrm{Tc}$-DTPA (diethylenetriaminepentaacetic acid (TCK-6, CIS bioindustries, Gif Sur Yvette, Cedex, France). At the end of the basal period, an insulin infusion was started. Blood glucose concentration was clamped at the mean fasting value obtained in the basal period with a variable glucose infusion via the Biostator CGIIS. After an equilibration period of $90 \mathrm{~min}$ the renal clearance measurements were repeated over a 90 min clearance period. The steady-state glucose infusion rate during the last $30 \mathrm{~min}$ of this period was calculated. Residual urine was determined by measuring radioactivity from ${ }^{99 \mathrm{~m}} \mathrm{Tc}-\mathrm{DTPA}$ in the pubic region before and after each voiding. After correction for background radioactivity determined over the chest, residual urine was calculated [7]. The clearance values obtained were corrected if calculated residual urine exceeded $20 \mathrm{ml}$.

Blood pressure was measured in duplicate by a semiautomatic device (Takeda UA-751, Japan) about $10 \mathrm{~min}$ after the injection of ${ }^{99 \mathrm{~m}} \mathrm{Tc}$-DTPA.

Blood samples for measurements of various substances were timed as follows. Plasma glucose: approximately every $30 \mathrm{~min}$ throughout the investigation and every $10 \mathrm{~min}$ for the last $30 \mathrm{~min}$ of each of the clearance periods. For immediate adjustment of the readings of the continuous glucose analyser in the Biostator CGIIS, plasma glucose concentration was measured with an automated glucose oxidase method (Glucose Analyser 2, Beckman Instruments, Fullerton Calif., USA) and the continuous glucose analyser adjusted accordingly. Plasma insulin and C-peptide: every 30 min during each of the clearance periods. $3-{ }^{3} \mathrm{H}$-glucose: every $30 \mathrm{~min}$ throughout the study and every $10 \mathrm{~min}$ for the last $30 \mathrm{~min}$ of each of the clearance periods. ${ }^{99 m}$ Tc-DTPA: every 30 min. Lithium, sodium and potassium: at the beginning and end of each clearance period.

Calculations. The renal clearances of ${ }^{99 \mathrm{~m}} \mathrm{Tc}-\mathrm{DTPA}$, lithium $\left(\mathrm{C}_{\mathrm{Li}}\right)$, potassium and sodium were calculated as the ratio between the urinary excretion rate and the mean plasma concentration during the $90 \mathrm{~min}$ clearance periods. For ${ }^{99 \mathrm{~m}}$ Tc-DTPA and lithium, the plasma concentration was calculated as the mean interpolated plasma concentration [8]. As a measure of extracellular fluid volume, the apparent volume of distribution of ${ }^{99 \mathrm{~m}} \mathrm{Tc}$-DTPA was calculated for the last clearance period, which started at least 210 min after the injection of ${ }^{99 m}$ Tc-DTPA where the final slope of the time-activity curve for ${ }^{99 m}$ Tc-DTPA has been reached [9]. During steady-state, the excreted amount of a tracer $(\mathrm{U} \cdot \mathrm{V})$, is equal to the amount of tracer present in the subject at the beginning of a clearance period $(t=1)$ minus the amount of tracer present in the subject at the end of the clearance period $(t=2)$. Assuming that the plasma concentration at any time, $\mathrm{P}_{\mathrm{t}}$ reflects the true mean concentration in the volume of distribution for the tracer $\left(V_{D}\right)$, the relationship can be written

(1) $U \cdot V=P_{1} \cdot V_{D}-P_{2} \cdot V_{D}$

which is rearranged:

(2) $\mathrm{V}_{\mathrm{D}}=\mathrm{U} \cdot \mathrm{V} /\left(\mathbf{P}_{1}-\mathbf{P}_{2}\right)$.

The absolute proximal tubular reabsorption rate of water was calculated as (glomerular filtration rate $(\mathrm{GFR})-\mathrm{C}_{\mathrm{Li}}$ ), and the absolute proximal reabsorption rate of sodium as plasma sodium concentration multiplied by the absolute proximal reabsorption of water. The fractional reabsorption of sodium and water in the proximal tubules was determined as $1-\left(\mathrm{C}_{\mathrm{L}} / \mathrm{GFR}\right)$. The absolute distal reabsorption rate of water was calculated as $\mathrm{C}_{\mathrm{Li}}$ - urine flow and the fractional distal water reabsorption was calculated as 1 - urine flow $/ \mathrm{C}_{\mathrm{L}:}$. The absolute distal reabsorption rate of sodium was calculated as plasma sodium concentration multiplied by the difference between $\mathrm{C}_{\mathrm{Li}}$ and sodium clearance, and the fractional distal sodium reabsorption was determined as 1 - sodium clearance $/ \mathrm{C}_{\mathrm{L}}$.

In the diabetic patients osmolar clearance induced by glucosuria was calculated from the urinary glucose excretion rate and estimated plasma osmolarity (two times the sum of plasma sodium and plasma potassium concentrations plus plasma glucose concentration) as previously described [10].

As measure of insulin sensitivity, the metabolic clearance rate of glucose during the last $30 \mathrm{~min}$ of each clearance period was calculated as the rate of glucose infusion per unit surface divided by the ambient plasma glucose concentration. Since this approach has been criticized, the insulin sensitivity index was calculated according to Bergman et al. [11] as the difference between the rate of disappearance of glucose $\left(R_{d}\right)$ during the last $30 \mathrm{~min}$ of insulin infusion and during the basal period divided by the product of the ambient plasma glucose concentration during this period and the increment in plasma insulin concentration produced by insulin infusion. For this purpose, plasma glucose concentration was measured every $10 \mathrm{~min}$ dur- 
Table 2. Effects of insulin infusion on plasma insulin concentration, plasma glucose concentration and metabolic clearance rate of glucose in ten Type 2 (non-insulin-dependent) diabetic patients and eight healthy control subjects

\begin{tabular}{|c|c|c|c|c|}
\hline & Type 2 diabe & & Healthy subje & \\
\hline & Basal & Insulin & Basal & Insulin \\
\hline Plasma insulin $(\mathrm{pmol} / \mathrm{ml})$ & $0.12 \pm 0.05^{b}$ & $0.56 \pm 0.15^{a}$ & $0.05 \pm 0.02$ & $0.41 \pm 0.07$ \\
\hline CV (insulin) (\%) & $12.2 \pm 4.7$ & $6.3 \pm 3.5$ & $21.7 \pm 10.0$ & $8.3 \pm 4.9$ \\
\hline Plasma glucose $(\mathrm{mmol} / \mathrm{l})$ & $9.9 \pm 3.5^{\mathrm{a}}$ & $10.0 \pm 4.0^{\mathrm{a}}$ & $5.3 \pm 0.5$ & $5.2 \pm 0.4$ \\
\hline $\mathrm{CV}($ glucose $)(\%)$ & $1.0 \pm 0.5$ & $3.2 \pm 1.8$ & $1.4 \pm 1.3$ & $5.1 \pm 1.9$ \\
\hline $\begin{array}{l}\text { Metabolic clearance rate of } \\
\text { glucose }\left(\mathrm{ml} \cdot \mathrm{min}^{-1} \cdot \mathrm{m}^{-2}\right)\end{array}$ & & $155 \pm 62^{b}$ & & $320 \pm 69$ \\
\hline
\end{tabular}

CV: Coefficient of variation. Mean $\pm S D$ indicated

${ }^{a} p<0.05$ as compared to the corresponding clearance period in the control subjects; ${ }^{\mathrm{b}} p<0.01$ as compared to the corresponding clear- ance period in the control subjects; $c p<0.005$ as compared to the corresponding value in the control subjects

Table 3. Effects of insulin infusion on kidney function and serum electrolytes in ten Type 2 (non-insulin-dependent) diabetic patients and eight healthy control subjects

\begin{tabular}{|c|c|c|c|c|}
\hline & Type 2 diabs & ents & Healthy sub & \\
\hline & $\overline{\text { Basal }}$ & Insulin & Basal & Insulin \\
\hline Glomerular filtration rate $\left(\mathrm{ml} \cdot \mathrm{min}^{-1} \cdot 1.73 \mathrm{~m}^{-2}\right)$ & $104 \pm 24$ & $105 \pm 27$ & $91 \pm 11$ & $91 \pm 8$ \\
\hline Lithium clearance $\left(\mathrm{ml} \cdot \min ^{-1} \cdot 1.73 \mathrm{~m}^{-2}\right)$ & $26 \pm 3$ & $25 \pm 4$ & $24 \pm 4$ & $24 \pm 7$ \\
\hline Plasma sodium concentration $\left(\mathrm{mmol} \cdot 1^{-1}\right)$ & $137 \pm 2$ & $137 \pm 2$ & $137 \pm 2$ & $138 \pm 2^{\mathrm{a}}$ \\
\hline Fractional excretion of sodium $(\%)$ & $1.8 \pm 1.0$ & $0.7 \pm 0.4^{\mathrm{b}}$ & $1.8 \pm 0.5$ & $0.9 \pm 0.3^{b}$ \\
\hline Urine flow rate $\left(\mathrm{ml} \cdot \mathrm{min}^{-1} \cdot 1.73 \mathrm{~m}^{-2}\right)$ & $3.0 \pm 1.3$ & $3.1 \pm 0.9$ & $3.2 \pm 2.0$ & $4.5 \pm 1.6$ \\
\hline Plasma potassium concentration $\left(\mathrm{mmol} \cdot \mathrm{I}^{-1}\right)$ & $4.1 \pm 0.1$ & $3.6 \pm 0.2^{b}$ & $3.9 \pm 0.2$ & $3.5 \pm 0.2^{b}$ \\
\hline
\end{tabular}

Mean \pm SD indicated.

${ }^{\mathrm{a}} p<0.05$ basal period vs insulin infusion period; ${ }^{\mathrm{b}} p<0.01$ basal period vs insulin infusion period

ing the steady-state periods. Thus, the insulin sensitivity index indicates the change in the metabolic clearance rate of glucose per unit change in plasma insulin concentration. During insulin infusion, the glucose infusion rate necessary to maintain a constant blood glucose concentration during the last $30 \mathrm{~min}$ of the clearance period was used as $R_{d}$ assuming suppression of hepatic glucose production, for the basal period $R_{d}$ was calculated as previously described [12].

Analyses. Urine and serum concentrations of lithium were determined by atomic absorption spectrophotometry (Perkin Elmer 1100 B, Norwalk, Conn., USA) as described by Amdisen [13]. Urine and plasma concentrations of sodium and potassium were determined by routine flame emission spectrophotometry. Plasma and urinary glucose concentrations were measured by the hexokinase method [14].

Plasma insulin concentration and plasma C-peptide concentrations were measured by radioimmunoassay $[15,16]$.

\section{Statistical analysis}

For comparisons within groups the Wilcoxon test for paired comparisons with Pratts correction was used [17]. For comparisons between groups, the Mann-Whitney test was used. A p-value $<0.05$ was considered significant.

\section{Results}

Results are shown in Tables 1,2,3, and 4 and in Figure 1. As compared to the age-matched control group, the patients with Type 2 diabetes had significantly higher body mass index $(p<0.05)$, blood pressure $(p<0.05)$, plasma glucose concentration $(p<0.05)$ and fasting plasma insulin concentration $(p<0.01)$ (Table 1 and Table 2). Fasting plasma $\mathrm{C}$-peptide concentrations were significantly elevated in the diabetic subjects $(0.94 \pm 0.40$ vs $0.49 \pm$ $0.19 \mathrm{pmol} / \mathrm{ml}, p<0.01$ ). Plasma insulin and glucose concentrations during each of the clearance periods are shown in Table 2. During insulin infusion, the plasma insulin concentration in the patients was significantly higher than in the control subjects, but the mean absolute increment in plasma insulin concentrations produced by insulin infusion was about the same in the diabetic subjects and the control subjects $(0.44 \pm 0.13$ vs $0.36 \pm 0.07 \mathrm{pmol} / \mathrm{ml}$, NS). Both the metabolic clearance rate of glucose during the last $30 \mathrm{~min}$ of insulin infusion and the calculated insulin sensitivity index were significantly lower in the diabetic patients $(p<0.01$ and $p<0.005$, respectively) (Table 2 ).

Sodium clearance declined during insulin infusion in both diabetic and control subjects, while the GFR and the output of water from the straight part of the proximal tubules into the thin descending limb of Henle's loop as estimated by lithium clearance remained unchanged (Table 3). Consequently, the proximal reabsorption rate of sodium and water was unchanged. Fractional distal sodium reabsorption increased significantly, while distal water reabsorption was unchanged. Calculated absolute distal reabsorption rate of sodium did not change signifi- 
Table 4. Effects of insulin infusion on calculated segmental renal tubular reabsorption in ten Type 2 (non-insulin-dependent) diabetic patients and eight healthy control subjects

\begin{tabular}{|c|c|c|c|c|}
\hline \multirow[b]{3}{*}{$\begin{array}{l}\text { Abşolute proximal reabsorption rate of water } \\
\left(\mathrm{ml} \cdot \min ^{-1} \cdot 1.73 \mathrm{~m}^{-2}\right)\end{array}$} & \multicolumn{2}{|c|}{ Type 2 diabetic patients } & \multicolumn{2}{|c|}{ Healthy subjects } \\
\hline & Basal & Insulin & Basal & Insulin \\
\hline & $79 \pm 22$ & $81 \pm 25$ & $67 \pm 11$ & $67 \pm 10$ \\
\hline $\begin{array}{l}\text { Absolute proximal reabsorption rate of sodium } \\
\left(\mathrm{mmol} \cdot \mathrm{min}^{-1} \cdot 1.73 \mathrm{~m}^{-2}\right)\end{array}$ & $10.8 \pm 3.0$ & $11.1 \pm 3.4$ & $9.2 \pm 1.5$ & $9.2 \pm 1.4$ \\
\hline $\begin{array}{l}\text { Fractional proximal reabsorption rate of sodium and } \\
\text { water }(\%)\end{array}$ & $75 \pm 4$ & $76 \pm 5$ & $73 \pm 5$ & $73 \pm 7$ \\
\hline $\begin{array}{l}\text { Absolute distal tubular reabsorption rate of sodium } \\
\left(\mathrm{mmol} \cdot \mathrm{min}^{-1} \cdot 1.73 \mathrm{~m}^{-2}\right)\end{array}$ & $3.3 \pm 0.4$ & $3.3 \pm 0.6$ & $3.1 \pm 0.6$ & $3.2 \pm 0.9$ \\
\hline $\begin{array}{l}\text { Absolute distal tubular reabsorption rate of water } \\
\left(\mathrm{ml} \cdot \min ^{-1} \cdot 1.73 \mathrm{~m}^{-2}\right)\end{array}$ & $23 \pm 3$ & $21 \pm 4$ & $21 \pm 5$ & $20 \pm 7$ \\
\hline Fractional distal tubular reabsorption rate of sodium (\%) & $92.9 \pm 4.1$ & $97.1 \pm 1.5^{\mathrm{a}}$ & $93.1 \pm 1.1$ & $96.5 \pm 0.6^{\mathrm{a}}$ \\
\hline Fractional distal tubular reabsorption rate of water (\%) & $88 \pm 5$ & $87 \pm 4$ & $87 \pm 8$ & $79 \pm 11$ \\
\hline
\end{tabular}

Mean \pm SD indicated.

${ }^{a} p<0.01$ basal period vs insulin infusion period

cantly (Table 4). Potassium clearance and plasma potassium concentrations declined with increasing plasma insulin concentrations. Plasma sodium concentration did not change significantly in the diabetic subjects, in the healthy subjects a minor but significant increase was observed during insulin infusion. No significant difference in the pattern of response of any of the parameters mentioned was detected between the diabetic subjects and the control subjects. In the control group insulin infusion reduced sodium clearance to $51 \pm 13 \%$ of the baseline value, while in the diabetic group, it declined to $40 \pm 10 \%$ of the baseline value. The median reduction in sodium clearance during insulin infusion was $12 \%$ higher in the diabetic group $(95 \%$ confidence interval for this difference was $3 \%$ to $22 \%$ ). The concentration-response curve for the effect of insulin on renal sodium clearance was nearly identical in Type 2 diabetic patients and in control subjects (Fig. 1).

Glucose-induced osmolar clearance was minimal in the diabetic patients both in the basal clearance period (median value $0.01 \mathrm{ml} / \mathrm{min}$, range $0-0.6$ ) and during insulin infusion (median value $0.01 \mathrm{ml} / \mathrm{min}$, range $0-0.8$ ) corresponding to $0.0 \%$ (range $0.0-1.9$ ) and $0.0 \%$ (range $0.0-3.3$ ) of lithium clearance during the basal clearance period and during insulin infusion, respectively.

When compared to the control group, baseline GFR was significantly higher in the diabetic patients without correction for body surface area $(120 \pm 27$ vs $97 \pm$ $\left.17 \mathrm{ml} \cdot \min ^{-1}, p<0.05\right)$, but after correction for surface this difference was no longer significant $(p=0.17)$, although mean GFR was still $14 \mathrm{ml} \cdot \mathrm{min}^{-1} \cdot 1.73 \mathrm{~m}^{-2}$ higher in the diabetic patients. Similarly, estimated extracellular fluid volume was significantly elevated in the diabetic patients without correction for body surface area $(18.9 \pm 2.9$ vs $15.6 \pm 2.11, p<0.05)$ but not after correction for body surface $\left(16.3 \pm 2.1\right.$ vs $\left.14.8 \pm 2.01 \cdot 1.73 \mathrm{~m}^{-2}, p=0.20\right)$. No differences in calculated segmental tubular sodium handling emerged, specifically both absolute and fractional proximal tubular sodium reabsorption rates were not significantly elevated in the diabetic patients.
Residual urine exceeding $20 \mathrm{ml}$ was observed in 10 of 32 voidings in the healthy control group, and in 18 of 40 voidings in the diabetic patients. There was no predictable pattern in the amount of residual urine observed and in several subjects only one or two voidings were associated with significant residual urine. To exemplify the impact of residual urine on renal excretion measurements, the coefficient of variation for GFR measured in the basal period and during insulin infusion was $5.9 \%$ in the diabetic patients when using correction for residual urine and $23.3 \%$ without.

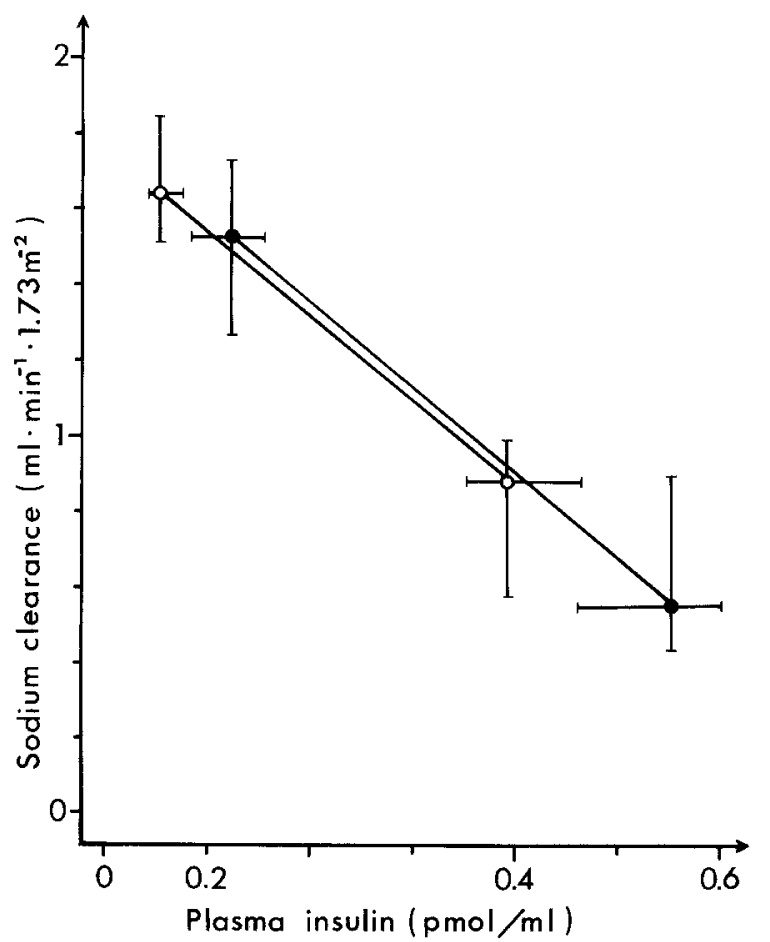

Fig. 1. The effect of insulin infusion on sodium clearance and plasma insulin concentration during isoglycaemia in ten patients with Type 2 (non-insulin-dependent) diabetes mellitus (filled circles) and eight healthy subjects (open circles). Median and interquartile ranges indicated 


\section{Discussion}

In our study the sodium retaining effect of insulin is preserved in Type 2 diabetic patients with peripheral insulin resistance and fasting hyperinsulinaemia. The association between obesity, hypertension and Type 2 diabetes is well known $[1,2]$. Recent longitudinal studies demonstrated, that blood pressure and body weight increases several years before the development of Type 2 diabetes [18], and that hyperinsulinaemia is still seen 5 years after the diagnosis of diabetes [19] as previously suggested [20]. In our patients plasma immunoreactive insulin and plasma $\mathrm{C}$-peptide values were elevated. True plasma insulin was not measured, but despite elevated levels of proinsulin, true plasma insulin is also elevated in Type 2 diabetic subjects [21]. Thus, hyperinsulinaemia remains a candidate for explaining the sodium and water retention and the increased frequency of hypertension observed in Type 2 diabetes [22, 23].

The $95 \%$ confidence interval for the reduction in sodium clearance induced by insulin only leaves the possibility for a $3 \%$ greater response in the healthy subjects. Therefore, the risk that our study did not detect a resistance to the sodium retaining effect of insulin similar to the marked peripheral insulin resistance in the diabetic subjects is negligible. Originally, Rocchini et al. found that the sodium retaining effect of insulin was normal in young, obese non-diabetic subjects with peripheral insulin resistance [24]. Using the same dose of insulin, they observed a reduction in renal sodium excretion very similar to that observed in the present study.

The clinical characteristics of our study population is representative of patients with Type 2 diabetes attending our clinic [25]. Since the basic question was, whether peripheral insulin resistance was associated with renal insulin resistance, we included patients with more than one cause for insulin resistance (i.e. obesity, hypertension). Although antihypertensive treatment was stopped at least four weeks prior to study, a slight residual effect of antihypertensive treatment on insulin sensitivity is possible. However, the changes in insulin sensitivity induced by antihypertensive treatment are less than the $62 \%$ difference in insulin sensitivity index observed in the present study $[26,27]$.

The evaluation of dose response curves is conceptually difficult. Since baseline insulin levels differed despite similar sodium excretion rates, the absolute plasma insulin concentrations cannot be used directly in the interpretation of results. Thus, the changes in plasma insulin levels must be related to the baseline values. In our previous study using two different rates of insulin infusion, there was a linear relation between the mean absolute increment in plasma insulin and the mean reduction in sodium clearance [4]. Therefore, the absolute increment in plasma insulin levels was evaluated in relation to the change in sodium excretion. If the fractional change in circulating insulin levels is related to the change in renal sodium clearance, the conclusion would be that the sodium retaining effect of insulin is enhanced about two-fold in Type 2 diabetes.

Our subjects were studied at their ambient plasma glucose concentration. This is the pathophysiologically rele- vant situation and avoids a confounding influence of semiacute changes in plasma glucose on renal function and metabolic parameters. In particular euglycaemia obtained by insulin infusion prior to the study would have led to a reduction in renal sodium excretion and simultaneously an aggravation of hyperinsulinaemia as can be observed in previous studies [28]. Recently the importance of performing metabolic studies at the patient's own ambient glucose concentration was stressed by Bergman et al. [11].

Lithium clearance is a measure of endproximal tubular fluid delivery during osmotic diuresis [29], and during osmotic diuresis induced by glucosuria there is a dissociation of distal tubular delivery of water and of sodium [30]. However, glucosuria did not appreciably affect the present results.

The present study localized the renal tubular site of action of insulin distally to the proximal renal tubules in Type 2 diabetic patients as did several previous studies in healthy subjects $[4,31,32]$. In contrast, a study in five normal subjects studied on two occasions with and without overnight infusion of insulin at a low dose reported that insulin increased $1-\left(\mathrm{C}_{\mathrm{L}} / \mathrm{GFR}\right)$ slightly from 70.08 to $70.92 \%$ $(p<0.05)$, while fractional distal reabsorption rate of sodium increased non-significantly from 28.20 to $28.92 \%$ (NS) (the unusual numerical value of fractional distal reabsorption rate is calculated as $\left(\mathrm{C}_{\mathrm{Li}}\right.$-sodium clearance)/GFR instead of $\left(\mathrm{C}_{\mathrm{Li}}\right.$-sodium clearance $\left.) / \mathrm{C}_{\mathrm{Li}}\right)$ [28]. Estimated from the mean values reported, $\left(\mathrm{C}_{\mathrm{Li}}\right.$-sodium clearance) $/ \mathrm{C}_{\mathrm{Li}}$ increased from about 93.6 to $94.7 \%$ during insulin infusion. The minor change in $1-\left(\mathrm{C}_{\mathrm{L}} / \mathrm{GFR}\right)$ in a study with five subjects does not allow any firm conclusions.

A plausible cellular mechanism for insulin-induced renal sodium retention is stimulation of $\mathrm{Na}-\mathrm{K}$-ATPase, which is stimulated by insulin $[4,33]$. Animal experiments found no functional relationship between the effect of insulin on the $\mathrm{Na}^{+}-\mathrm{K}^{+}$pump and on cellular glucose metabolism [34]. In man, some authors have reported that cellular sodium-pump activity is insulin-resistant in obesity [35], while others have demonstrated a dissociation between the effects of insulin on forearm glucose uptake and sodium-potassium exchange [36]. In contrast to a study in young obese subjects [37], we observed a similar lowering effect of insulin on the plasma concentration of potassium in diabetic and non-diabetic subjects. There is no explanation for this discrepancy.

Recently, the sodium retaining effect of insulin was ascribed to the decline in plasma potassium, since it could be reversed by a simultaneous infusion of potassium [32]. However, there is ample in vitro evidence for direct effects of insulin on cellular electrolyte transport $[33,38]$. Experiments in isolated kidneys showed insulin-induced sodium retention despite an unchanged plasma potassium level [39], and the effects of chronic insulin infusion to reduce sodium excretion did not bear any relation to changes in plasma potassium levels [40]. Moreover, potassium loading per se is natriuretic in normal man. Although the effect has been related to concurrent changes in plasma potassium and aldosterone concentrations, the mechanism is poorly understood [41]. 
In Type 1 (insulin-dependent) diabetic patients absolute and fractional proximal reabsorption rate of fluid and sodium is enhanced as compared to healthy subjects in a comparable sodium balance, while lithium clearance is normal [42-44]. In the present study in Type 2 diabetic patients, we found no significant difference in any index of segmental tubular function, although both absolute and fractional proximal reabsorption rate of sodium and water was slightly elevated in the diabetic patients. In a previous study, Mbanya et al. [45] reported that both fractional lithium clearance and fractional excretion of sodium in the distal tubule was lower in hypertensive Type 2 diabetic patients, but not significantly different from control subjects in normotensive diabetic patients. Although our study was not designed to detect such differences, there was no tendency to a similar difference. Further studies are necessary to clarify this issue. In non-diabetic patients with essential hypertension, most studies concluded that renal tubular function is normal [46].

A relationship between hyperinsulinaemia and high blood pressure has been established in several studies [1, $2,47]$. Hypertension in diabetes is accompanied by sodium and volume retention [22, 23, 48, 49]. The preserved sodium retaining effect of insulin suggests that insulin induced sodium retention may contribute to the pathogenesis of hypertension in Type 2 diabetes. However, longterm insulin infusion in dogs did not elevate blood pressure [40], and the frequency of hypertension is normal in patients with Type 1 diabetes without renal complications [50]. In a clinical study of the effect of short-term strict metabolic control in long-term Type 1 diabetic patients, intensified insulin treatment resulted in an increase in extracellular fluid volume without any detectable change in GFR or blood pressure [51]. Further studies on the role of insulin-induced sodium retention - if any - in the pathogenesis of hypertension are warranted.

Acknowledgements. The expert technical assistance of Ms. A. Forman and Ms. B.Mottlau is gratefully acknowledged. The Velux Foundation supplied the equiptment for measurement of lithium.

\section{References}

1. Reaven GM, Hoffman BB (1987) A role for insulin in the aetiology and course of hypertension. Lancet II: $435-437$

2. O'Hare JA (1988) The enigma of insulin resistance and hypertension. Insulin resistance, blood pressure and the circulation. Am J Med 84: 505-510

3. Landsberg L (1986) Diet, obesity and hypertension. An hypothesis involving insulin, the sympathetic nervous system, and adaptative thermogenesis. Q J Med 61: 1081-1090

4. Skøtt P, Hother-Nielsen O, Bruun NE, Giese J, Nielsen MD, Beck-Nielsen H, Parving H-H (1989) Effects of insulin on kidney function and sodium excretion in healthy subjects. Diabetologia 32: 694-699

5. DeFronzo RA (1981) The effects of insulin on renal sodium metabolism. A review with clinical implications. Diabetologia 21: 165-171

6. O'Hare JP, Corrall RJM (1988) De natrio diabeticorum. Increased exchangeable sodium in diabetes. Diab Med 5:22-26

7. Lindbjerg IF, Brandt NJ (1964) Indirect determination of the volume of residual urine with ${ }^{135} \mathrm{I}$-labelled hippuran. Acta Chir Scand 127: 675-680
8. Holstein-Rathlou N-H, Svendsen UG, Leyssac PP (1982) Proxi$\mathrm{mal}$ and distal tubular reabsorption during isotonic volume expansion in patients with essential hypertension as estimated by means of combined ${ }^{51} \mathrm{Cr}$-labelled EDTA clearance. Clin Sci 63 : $219 \mathrm{~s}-221 \mathrm{~s}$

9. Rehling M, Møller ML, Thamdrup B, Lund JO, Trap-Jensen J (1984) Simultaneous measurement of ${ }^{99 \mathrm{~m} T c-l a b e l l e d ~ d i e t h y l e n e-~}$ triaminepenta-acetate, ${ }^{51} \mathrm{Cr}$-labelled ethylenediaminetetra-acetate and inulin in man. Clin Sci 66: 613-619

10. Sk $\varnothing t t$ P, Hommel E, Bruun NE, Arnold-Larsen S, Parving H-H (1988) Effects of acetazolamide on kidney function in Type 1 (insulin-dependent) diabetic patients with diabetic nephropathy. Diabetologia 31: 806-810

11. Bergman RN, Hope ID, Yang YJ, Watanabe RM, Meador MA, Youn JH, Ader M (1989) Assessment of insulin sensitivity in vivo: a critical review. Diab Metab Rev 5: 411-429

12. Hother-Nielsen O, Beck-Nielsen H (1990) On the determination of basal glucose production rate in patients with Type 2 (non-insulin-dependent) diabetes using primed-continuous 3 ${ }^{3} \mathrm{H}$-glucose infusion. Diabetologia 33: 603-610

13. Amdisen A (1975) The estimation of lithium in urine. In: Johnson FN (ed) Lithium research and therapy. Academic Press, London, pp 181-195

14. Andersen I, Hannibal S (1983) Analytical and economical optimization of a glucose method with immobilized enzymes. J Automatic Chem 5: 188-192

15. Heding LG (1972) Determination of total serum insulin (IR) in insulin-treated diabetic patients. Diabetologia 8:260-266

16. Heding LG (1975) Radioimmunological determination of human C-peptide in serum. Diabetologia 13: 467-474

17. Rahe AJ (1974) Tables of critical values for the Pratt matched pair signed rank statistic. J Am Stat Ass 69: 368-373

18. Akahoshi M, Seto S, Matsuo T, Shimaoka K, Kodama K, Hashiba K (1990) Longitudinal analysis of blood pressure in diabetics and its relation to obesity -26 years of follow up study. $\mathrm{J}$ Hypertens 8 [Suppl 3]: S125

19. Niskanen LK, Uusitupa MI, Sarlund H, Siitonen O, Pyörälä K (1990) Five-year follow-up study on plasma insulin levels in newly diagnosed NIDDM patients and nondiabetic subjects. Diab Care $13: 41-48$

20. DeFronzo RA (1988) The triumvirate: $\beta$-cell, muscle, liver. A collusion responsible for NIDDM. Diabetes 37: 667-687

21. Saad MF, Kahn SE, Nelson RG, Pettitt DJ, Knowler WC, Schwartz MW, Kowalyk S, Bennett PH, Porte D (1990) Disproportionately elevated proinsulin in Pima Indians with non-insulin-dependent diabetes mellitus. J Clin Endocrinol Metab 70: 1247-1253

22. Beretta-Piccoli C, Weidmann P (1982) Body sodium-blood volume state in nonazotemic diabetes mellitus. Mineral Electrolyte Metab 7: 36-47

23. Weidmann P, Beretta-Piccoli C, Trost BN (1985) Pressor factors and responsiveness accompanying diabetes mellitus. Hypertension 7 [Suppl 2]: 33-42

24. Rocchini AP, Katch V, Kveselis D, Moorehead C, Martin M, Lampman R, Gregory M (1989) Insulin and renal sodium retention in obese adolescents. Hypertension 14: 367-374

25. Gall M-A, Skøtt P, Damsbo P, Vaag A, Bech K, Dejgaard A, Rossing P, Beck-Nielsen H, Parving H-H (1988) The prevalence of micro- and macroalbuminuria, retinopathy, arterial hypertension and large vessel disease in Type 2 (non-insulin-dependent) diabetes mellitus. Diabetologia 31: $492 \mathrm{~A}$

26. Pollare T, Lithell H, Berne C (1989) A comparison of the effects of hydrochlorothiazide and captopril on glucose and lipid metabolism in patients with hypertension. N Engl J Med 321:868-873

27. Pollare T, Lithell H, Selinus I, Berne C (1989) Sensitivity to insulin during treatment with atenolol and metoprolol: a randomised, double blind study of effects on carbohydrate and lipoprotein metabolism in hypertensive patients. Br Med J 298: 1152-1157

28. Trevisan R, Fioretto P, Semplicini A, Opocher G, Mantero F, Rocco S, Remuzzi G, Morocutti A, Zanette G, Donadon V, 
Perico N, Giorato C, Nosadini R (1990) Role of insulin and atrial natriuretic peptide in sodium retention in insulin-treated IDDM patients during isotonic volume expansion. Diabetes 39:289-298

29. Leyssac PP, Holstein-Rathlou N-H, Skøtt P, Alfrey AC (1990) A micropuncture study of proximal tubular transport of lithium during osmotic diuresis. Am J Physiol 258: F1090-F1095

30. Skøtt P, Bruun NE, Giese J, Holstein-Rathlou N-H, Leyssac PP (1987) What does lithium clearance measure during osmotic diuresis? Clin Sci 73: 126-127

31. Nørgaard K, Jensen T, Skøtt P, Thorsteinsson B, Nielsen MD, Bruun NE, Giese J (1989) Volume expansion during hyperinsulinaemia induces a parallel increase in glomerular filtration rate and lithium clearance in normal man. Diabetologia 32: 523 (Abstract)

32. Friedberg CE, Koomans HA, Bijlsma JA, Mees EJD (1990) Acute sodium retention by insulin: a potassium effect? Diabetologia 33: 21 (Abstract)

33. Clausen T, Everts ME (1989) Regulation of the $\mathrm{Na}, \mathrm{K}$-pump in skeletal muscle. Kidney Int 35: 1-13

34. Clausen T, Flatman JA (1987) Effects of insulin and epinephrine on $\mathrm{Na}^{-}-\mathrm{K}^{+}$and glucose transport in soleus muscle. Am J Physiol 252: E492-E499

35. Mott DM, Clark RL, Andrews J, Foley JE (1985) Insulin-resistant $\mathrm{Na}^{+}$pump activity in adipocytes from obese humans. Am J Physiol 249: E160-E164

36. Ferrannini E, Taddel S, Santoro D, Natali A, Boni C, Del Chiaro D, Buzzigoli $G$ (1988) Independent stimulation of glucose metabolism and $\mathrm{Na}^{+}-\mathrm{K}^{+}$exchange by insulin in the human forearm. Am J Physiol 255: E953-E958

37. DeFronzo RA (1988) Obesity is associated with impaired insulin-mediated potassium uptake. Metabolism 37: 105-108

38. Moore RD (1983) Effects of insulin upon ion transport. Biochim Biophys Acta 737: 1-49

39. Nizet A, Lefebvre P, Crabbé J (1971) Control by insulin of sodium potassium and water excretion by the isolated dog kidney. Pflügers Arch 323: 11-20

40. Hall JH, Coleman TG, Mizelle HL, Smith MJ (1990) Chronic hyperinsulinemia and blood pressure regulation. Am J Physiol 258: F722-F731

41. Hené RJ, Koomans HA, Rabelink AJ, Boer P, Mees EJD (1988) Mineralocorticoid activity and the excretion of an oral potassium load in normal man. Kidney Int 34: 697-703

42. Brøchner-Mortensen J, Støckel M, Sørensen PJ, Nielsen AH, Ditzel J (1984) Proximal glomerulo-tubular balance in patients with Type 1 (insulin-dependent) diabetes mellitus. Diabetologia 27: 189-192

43. Skøtt P, Mathiesen ER, Hommel E, Gall M-A, Bruun NE, Parving $\mathrm{H}-\mathrm{H}$ (1989) The increased proximal tubular reabsorption of sodium and water is maintained in long-term insulin-dependent diabetics with early nephropathy. Scand J Clin Lab Invest 49: $419-425$

44. Hannedouche TP, Delgado AG, Gnionsahe DA, Boitard C, Lacour B, Grünfeld J-P (1990) Renal hemodynamics and segmental tubular reabsorption in early type 1 diabetes. Kidney Int 37: 1126-1133

45. Mbanya J-C, Thomas TH, Taylor R, Alberti KGMM, Wilkinson R (1989) Increased proximal tubular sodium reabsorption in hypertensive patients with Type 2 diabetes. Diab Med 6: 614 620

46. Bruun NE, Skøtt P, Nielsen MD, Rasmussen S, Schütten HJ, Leth A, Pedersen EB, Giese J (1990) Normal renal tubular response to changes of sodium intake in hypertensive man. $\mathrm{J}$ Hypertension 8: 219-227

47. Bonora E, Zavaroni I, Pezzarossa A, Bruschi F, Dall'Aglio E, Guerra L, Coscelli C, Butturini U (1987) Relationship between blood pressure and plasma insulin in non-obese and obese nondiabetic subjects. Diabetologia 30:719-723

48. Feldt-Rasmussen B, Mathiesen ER, Deckert T, Giese J, Christensen NJ, Bent-Hansen L, Nielsen MD (1987) Central role for sodium in the pathogenesis of blood pressure changes independent of angiotensin, aldosterone and catecholamines in Type 1 (insulin-dependent) diabetes mellitus. Diabetologia 30: 610-617

49. Hommel E, Mathiesen ER, Giese J, Nielsen MD, Schütten HJ, Parving H-H (1989) On the pathogenesis of arterial blood pressure elevation early in the course of diabetic nephropathy. Scand J Clin Lab Invest 49: 537-544

50. Parving H-H, Hommel E, Mathiesen E, Skøtt P, Edsberg B, Bahnsen M, Lauritzen M, Hougaard P, Lauritzen E (1988) Prevalence of microalbuminuria, arterial hypertension, retinopathy and neuropathy in patients with insulin dependent diabetes. $\mathrm{Br}$ Med J 296: 156-160

51. Mathiesen ER, Gall M-A, Hommel E, Skøtt P, Parving H-H (1989) Effects of short-term strict metabolic control on kidney function and extracellular fluid volume in incipient diabetic nephropathy. Diab Med 6:595-600

Received: 23 July 1990

and in revised form: 12 December 1990

Dr. P.Skøtt

Hvidøre Hospital

Emiliekildevej 1

DK-2930 Klampenborg

Denmark 